\title{
Legal Protection of Beauty Clinic Service Users in Indonesia: Problems and Legal Responsibility
}

\author{
Cahyani Utari $^{1}$, Sunny Ummul Firdaus ${ }^{2}$, Rehnalemkem Ginting ${ }^{2}$ \\ ${ }^{1}$ Post Graduate Student of Law, Sebelas Maret University, Indonesia \\ ${ }^{2}$ Lecturer in Faculty of Law, Sebelas Maret University, Indonesia \\ cahyani.utari9703@gmail.com
}

\begin{abstract}
This article aims to examine the form of legal protection and supervision and legal responsibilities related to the implementation of beauty clinic services as well as a description of the existing problems. Research results show that in practice many business actors do not do the things they should do because they are more concerned with material benefits, and less concerned with the dangers of the products they sell. It can be said if every class of consumers who perform treatment at a beauty clinic has the right to get legal protection if there are consequences of the treatment process that is detrimental to him. The rise of malpractice cases, the use of illegal and dangerous drugs, and incompetence of health workers to beauty clinic licenses has become a series of problems that must be addressed by the government through strengthening supervision aspects.
\end{abstract}

\section{Keywords}

beauty clinic; regulation; legal protection;

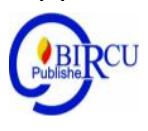

\section{Introduction}

The development of globalization related to the needs of modern society in the field of beauty has become without limits which impacts on culture and lifestyle to care for each individual. In Indonesia, the beauty of various beauty clinics in recent years has become more widespread, including Natasha, Erha, Larissa, Be Hati, and Ella, which promise beauty care products that are able to appeal to consumers.

The rapid development of the beauty business in its operation must be accompanied by fulfilling the rights and obligations of the relevant stakeholders. Based on the 1945 Constitution which contains the Rights and Obligations of citizens is guaranteed the right to get legal protection, the right to health and the right to obtain health services. This mandate is contained in the 1945 Constitution Article 28D paragraph (1) which reads "Everyone has the right to recognition, guarantee of protection, and fair legal certainty and equal treatment before the law and Article $28 \mathrm{H}$ paragraph (1) which reads:" Everyone has the right to live in physical and spiritual prosperity, to live, and to have a good and healthy living environment and the right to health services. "

Based on Article 1 letter a Regulation of the Minister of Health (Permenkes) No. 9 of 2014 concerning Clinics states that clinics are health service facilities that provide individual health services that provide basic and / or specialized medical services. Various kinds of products and health services in beauty clinics are offered with relatively affordable prices that offer a variety of services and cosmetics to enhance one's appearance. Body or skin care services are one of the services offered in the beauty industry today. Article 1 number 5 of Law Number 8 of 1999 concerning Consumer Protection states that services are any services in the form of work or achievements provided for the public to be used by consumers.

Health services at this beauty clinic are in great demand by consumers, of course, so that beauty causes widespread among the community. Consumer rights in Indonesia itself 
between employers and the government often neglects the rights of consumers both in providing public shipping and in selling products. As a result of the lack of application and supervision of the quality and quality standards of cosmetic products, the consumer's position is not protected, resulting in cases where cosmetic products purchased by the public for the purpose of beauty actually harm health In fact, behind the rapid growth of beauty clinics there are some negative sides, including many consumers who are apparently not compatible with the services and beauty products offered by beauty clinics.

This is certainly a disadvantage for users of beauty clinic services. Losses experienced by consumers usually arise because lack of information provided related to the situation and the side effects of the actions taken. Many adverse cases experienced by consumers of beauty clinics, such as the appearance of irritation on the face after using products from the beauty clinic, irritation can be in the form of pain and flushing on the face of the consumer. Furthermore, Ahmad Mahuri highlighted in terms of products used by health services, it was mentioned that if the extent of cosmetic ingredients was circulated in meeting the market needs that became a business field for businesses, both cosmetics that had a marketing authorization from the government to those not licensed from the government. . Activities like this are often used as a business area for business people who have bad intentions due to the weak position of consumers because there is no balanced protection to protect the rights of consumers.

However, with many beauty clinics there are some consumers who experience a discrepancy with the services and beauty products offered by the beauty clinic. Because there are many beauty clinic practices that promise instant results, the public must be vigilant because there is one case where a high school graduate woman who claims to be a beauty doctor to commit fraud and practice illegally. Now with the many illegal and dangerous cosmetics circulating, consumers are increasingly careful in choosing cosmetics to buy, because they are afraid to damage their skin (Hasibuan, 2019). Then there are experts who work in beauty clinics that are not in accordance with their fields, one of them is ADF victims aged 30 years old doing nose lengthening process in Makassar beauty clinic, but in the process this ADF experienced blindness in his left eye caused by injections from the base of the nose went up to his left eye and disturbed the neural network on the head. This becomes a legal problem with the practice of beauty clinics because the doctor who made the ADF initial nose extension is a general practitioner, but he practices in the beauty field.

The fact of such a problem is certainly contrary to the provisions contained in Law Number 29 of 2004 concerning Medical Practices, Law Number 36 of 2009 concerning Health, and Regulation of the Minister of Health of the Republic of Indonesia Number 9 of 2014 concerning Clinics. Therefore, in practice there are many actors businesses that don't do things that should be done because they think more about material benefits, and are less concerned with the dangers of the products they sell.

Based on the descriptions above with the implementation of consumer protection regulations in order to increase the dignity and awareness of consumers and indirectly encourage business people in carrying out business activities with a sense of responsibility. This article is intended to provide an explanation of the form of legal protection against supervision in carrying out legal responsibilities and the problematic implementation of beauty clinic services for consumers in Indonesia.

\section{Research Method}


This legal research uses the type of doctrinal or normative legal research conducted by examining library materials that are related to the issue of legal protection of beauty clinic service users in Indonesia. in this case, of course, must see the relevant legislation.

\section{Discussion}

\subsection{Form of Legal Protection and Supervision and Legal Responsibility in Carrying Out Beauty Clinic Services}

a. Perspective of the Consumer Protection

Act The government is responsible for fostering consumer protection that ensures the acquisition of consumer and business actors' rights and the implementation of consumer and business actor obligations. Related to the supervision itself of carrying out legal responsibilities towards the implementation of beauty clinic services is carried out by the government, the community, and non-governmental consumer protection institutions that have been described in Article 30 of Law Number 8 of 1999 concerning Consumer Protection.

The existence of a law concerning consumer rights will not necessarily guarantee legal protection for consumers. At this time there have been many cosmetics circulating that do not have a marketing authorization and are harmful to the health of its users which contain dangerous ingredients that can threaten the health and safety of life. In connection with this there is a great need for supervision and legal protection for consumers of businesses who try producing, selling, or distributing illegal cosmetic products. The consumers referred to here are users of illegal cosmetic products that contain hazardous ingredients and can endanger health. The intended businessperson is a person or business entity in the form of a legal entity or not a legal entity either producer, agent, sales, retailers related to cosmetic products. Thus the Consumer Protection Act number 8 of 1999 (UUPK) is indispensable in order to protect consumers.

The purpose of consumer protection is regulated in Article 3 of Law Number 8 of 1999 concerning Consumer Protection which includes:

1) To increase consumer awareness, ability and independence to protect themselves;

2) elevating the dignity of consumers by avoiding negative excesses in the use of goods and / or services;

3) increase consumer empowerment in an effort to choose, determine, and claim their rights as consumers;

4) create a consumer protection system in which there is legal certainty and information disclosure and access to information;

5) to foster awareness of business actors regarding the importance of consumer protection in order to grow honest and responsible attitudes in carrying out a business;

6) Improve the quality of goods and / or services that guarantee the continuity of the business of producing goods and / or services, and the health, comfort, security, and safety of consumers.

It can be said if every class of consumers who perform treatment at a beauty clinic has the right to get legal protection if there are consequences of the treatment process that is detrimental to him. The legal protection was born from a binding legal relationship between beauty clinics and consumers, where the legal relationship occurred since consumers came to the beauty clinic and received an explanation from doctors regarding the situation and how to handle and subsequent effects. The birth of Law Number 8 of 1999 concerning Consumer 
Protection aims to regulate the rights and obligations between consumers and business actors, so as to uphold the sense of security of beauty clinic consumers, as well as uphold the sense of responsibility of business actors for the products and services they offer. Beauty clinics as business people realize that they must be able to guarantee their consumers' rights are fulfilled in various fields.

\section{b. Forms of Government Oversight of Beauty Products}

The state is obliged to provide legal protection and the right to health, so that beauty clinic business practitioners obey all applicable regulations related to their implementation, increasing their responsibilities as business actors to their consumers. The use of drugs or creams given by beauty clinic doctors cannot be separated from the supervision of the Food and Drug Supervisory Agency (BPOM) which based on Article (2) BPOM Head Regulation No. 14 of 2014 has the task of implementing policies in the field of drug and food control, which includes supervision for therapeutic products, narcotics, psychotropic substances, addictive substances, traditional medicines, cosmetics, complement products. The marketing of creams sold by beauty clinics must have permission from BPOM.

Cosmetics that do not have a marketing authorization number from the National Agency for Drug and Food Control (BPOM) show that cosmetics are not safe to use because they do not go through the stages of laboratory testing as one of the stages to obtain a marketing authorization number according to the Minister of Health Regulation Number 1175 / Menkes / Per / XII / 2010 concerning Cosmetics Notification.

In Article (2) of the Regulation of the Head of the Drug and Food Supervisory Agency Number 18 Year 2015 Regarding Technical Requirements for Cosmetic Materials mention: 1) Cosmetics must meet the quality requirements as stated in the Indonesian Cosmetics Codex or other recognized standards or in accordance with statutory provisions. 2) Cosmetics Material referred to in paragraph (1) is in the form of materials that may be used in making Cosmetics. 3) In addition to the Cosmetics Material as mentioned in paragraph (1) and paragraph (2), other materials are prohibited from being used in the manufacture of Cosmetics. In this case in providing consumer protection against illegal beauty products, it is necessary to supervise the government by the preventive supervision system, special surveillance system, and incidental surveillance system. This surveillance system is carried out early on cosmetic products so that the hope is that the potential of law enforcement agencies can run optimally, effectively and efficiently. This special surveillance system is meant to be an active supervision of cosmetics cases which can have a wide impact that is not only in terms of health but also in terms of social and economic aspects. When signs are found that indicate a certain case of abuse of marketing authorization in the field, the system encourages law enforcement to handle it with specific actions based on the specificity of violations committed. Incidental surveillance system is a process of supervision carried out by law enforcement authorities on the safety and safety of legal cosmetics carried out by means of unannounced inspections.

\section{c. Form of legal responsibility for the implementation of beauty clinics}

Every business actor is burdened with responsibility for bad behavior that can harm consumers. The relationship between doctors in beauty clinics and users of beauty clinic services gives birth to the rights and obligations of the parties and establishes their respective legal responsibilities. The theory of responsibility in legal actions (tort liability), one of them is the theory of absolute liability due to acts that violate the law without questioning errors 
(strict liability) which are based on intentional good actions, which means that even though it is not their fault, they are still responsible for the losses arising from their actions.

Based on the provisions of Article 19-21 of the Consumer Protection Act, it basically regulates the responsibilities of the beauty clinic business actor consisting of the responsibility of the beauty clinic, the first being responsibility based on mistakes, in the event of procedural errors in diagnosis, actions and medications given, the clinical business actor beauty must be responsible for losses suffered by consumers, the second risk responsibility for actions to be taken, for example actions that will cause side effects such as lasers or other operative media actions, the third is product responsibility ie drugs and substances obtained during treatment at the beauty clinic and the fourth is professional responsibility which means there are authorized health workers who can take action in the beauty clinic.

This is where the role of government is needed in dealing with issues surrounding the supervision of cosmetics distribution in the community. The government should be responsible for organizing consumer protection development so as to guarantee the acquisition of consumer and business actors' rights and the implementation of consumer and business actor obligations. Guidance by the government for the implementation of consumer protection as intended is carried out by the minister and / or other relevant technical officials as regulated in Article 29 and Article 30 of Law Number 8 of 1999 concerning Consumer Protection. If we see in the general explanation of Law Number 8 of 1999 concerning Consumer Protection it is stated that the rule of law that protects consumers is not intended to shut down the businesses of businesses, but instead encourages a healthy business climate, as well as the birth of resilient companies in facing competition through the way of providing goods and / or quality services.

Violation of medical rights and obligations will result in legal consequences, if it is done by a doctor, the medical community will take action through the ethical code assemblies and the medical discipline assembly that will be carried out by the MKEK (Medical Ethics Council). Each business actor must be responsible for providing compensation for losses suffered by consumers due to the use of goods and / or services traded by business actors. Likewise, consumers of illegal beauty clinics who suffer losses, the beauty clinic must be responsible for compensating these losses Concerning the responsibility of business actors to compensate for consumer losses is regulated in Article 19 of the Consumer Protection Act and Article 58 of the Health Act. To obtain compensation for losses suffered, consumers can demand civil liability from business actors including:

1) Liability for losses caused by default

This responsibility arises with the legal relationship that occurs when consumers come to a beauty clinic for treatment or for treatment. This relationship is between doctors, consumers, and beauty clinics in the form of an engagement for health care services. This relationship then appears an agreement or is called an agreement therapeutic. Accountability for defaults on the relationship between doctor and patient that causes harm, including medical actions that are contrary to the standards of professional medias or medical service standards. The form of losses is in the form of material as measured by the value of money, especially the cost of care, travel costs, and the cost of medicines for healing, then immaterial losses are based on unlawful acts.

2) Liability for losses due to unlawful acts. 
This responsibility arises with the existence of consumers of beauty clinic services who want to sue the beauty clinic and / or doctor based on acts against the law, so the consumer must prove that the actions of skin health services that have been carried out by the business actor or doctor in the beauty clinic have fulfilled the elements of the act against the law. These elements include: a) the existence of acts against the law if it is contrary to the rights of others, their own legal obligations, the decency of the community, the attitude of caution that should be heeded in the social association of themselves or other people's objects; b) there is a mistake To be able to sue the doctor with lawsuits, the consumer must be able to prove the doctor's mistake in carrying out his obligations so as to cause harm; c) there is a causal relationship between unlawful acts and losses, where consumers must be able to prove that health services are detrimental to themselves.

\subsection{Legal Protection Issues Regarding the Implementation of Beauty Clinic Services in Indonesia}

The progress in the industry that is so rapid also affects the emergence of a free market that makes competition among traders tight, especially in terms of attracting consumers in selling goods to be traded. One of the best-selling products in the market is cosmetics. The most common form of abuse in a cosmetic product in a beauty clinic is the use of hazardous chemicals or additives as mixtures in cosmetics that are traded. In Article 106 Paragraph (1) of Law Number 36 Year 2009 concerning Health, pharmaceutical preparations and medical devices can only be circulated when obtaining a marketing authorization. Behind the rapid growth of beauty clinics on consumer products turned out to be stricken with problems that do not match the beauty products issued by beauty clinics. Among these consumer complaints are usually related to the condition of consumers who get worse skin conditions and various weaknesses in consumers so that they do not have a safe position compared to the position of the manufacturer or business actors who are relatively stronger in many ways, then consumers will generally feel the impact.

The form of supervision conducted by the Central Bureau of Drug and Food Control (POM) to date is still experiencing problems related to safety, efficacy, and quality of cosmetics, which are still found, namely the existence of illegal circulation of cosmetics or who do not have permission by unscrupulous persons. One of the factors contributing to the rampant problem of cosmetics circulation in Indonesia is the overlapping regulations between related sectors, resulting in a follow-up to the optimal and inconsistent sanction recommendations.

Cosmetic products that tend to be circulated without permission by unauthorized parties are usually lifestyle, life-saving, and other cosmetics that are sought after by the public. Based on monitoring data from the Central Bureau of Drug and Food Control POM 20132017, the findings are dominated by cosmetic preparations for fragrances, hair, eyes, makeup and skin care. When viewed from the type of cosmetics, branded cosmetics at relatively cheap prices more often do not have a marketing authorization than cosmetics that have been registered and have a marketing authorization.

The existence of various weaknesses in consumers so that they do not have a safe position compared to the position of producers or business actors who are relatively stronger in many ways, so consumers will generally feel the impact. Thus, in order to make some efforts to provide adequate protection and cover the interests of consumers is an important thing and must be followed up. Other acquisitions, problems which according to the author become the main source regarding the supervision of health clinic licenses and medical 
practice licenses on health clinic. Starting from the competency of health workers that are not based on specific nomenclature, the government in this case the Ministry of Health must immediately issue clear and rigid regulations so that users of beauty health clinic services at least feel protected from aspects of the competency of health workers and the Food and Drug Supervisory Agency in collaboration with agencies The regions must routinely carry out unannounced inspections of a number of beauty health clinics that are currently in existence while the issue of a license for the practice of beauty health clinics is the duty of the relevant Regional Government. The task of the Regional Government is not only about 'issuing licenses of practice' but also being responsible for monitoring the suitability of licenses that have been issued with facts on the ground.

\section{Conclusion}

Through the elaborations of this article as the author conveyed in the previous section that it can be seen that the form of legal protection under the Consumer Protection Act aims to regulate the rights and obligations between consumers and business actors, so as to uphold the sense of security for consumers of beauty clinics, as well as Uphold the sense of responsibility of business actors for the products and services it offers with the form of government supervision of illegal beauty products with a preventive supervision system, a special surveillance system, and an incidental surveillance system. Every business actor is burdened with responsibility for bad behavior that can harm consumers who based on the provisions of Article 19-21 of the Consumer Protection Act states that basically regulates the responsibilities of the beauty clinic business actor consisting of the responsibilities of the beauty clinic is responsibility based on mistakes, responsibility of risk for actions what to do, and product responsibility. Behind the rapid growth of beauty clinics on consumer products, there are problems that are incompatible with beauty products issued by beauty clinics. Among the complaints of consumers are usually related to the condition of consumers' skin that gets worse and there are various weaknesses in consumers so they do not have a safe position compared to the position relatively stronger producers or business actors.

\section{References}

Muhammad, Abdulkadir, (2010). Hukum Perusahaan Indonesia,Bandung: Citra Aditya Bakti. Miru, Ahmadi, (2011), Prinsip-Prinsip Perlindungan Hukum Bagi Konsumen Di Indonesia, Jakarta: Raja Grafindo Persada.

Miru, Ahmadi and Yodo, Sutarman, (2011), Hukum Perlindungan Konsumen, Jakarta: Raja Grafindo Persada.

Widjaja, Gunawan, (2000), Hukum Tentang Perlindungan Konsumen, Jakarta: Gramedia Pustaka Utama.

Syawali, Husni and Imaniyati, Neni Sri, (2000), Hukum Perlindungan Konsumen, Bandung: Mandar Maju.

Safitri, (2005).Sengketa Medik, Alternatif Penyelesaian Perselisihan Antara Dokter Dengan Pasien, Jakarta:Media.

Shofie, Yusuf, (2000), Perlindungan Konsumen dan Instrumen-Instrumen Hukumnya, Bandung: Citra Aditya Bakti. 
Hasibuan, S. W., Nasution, Y., and Siregar, S. (2019). The Effect of Health and Religious Beliefs on Consumer Consciousness of Using Halal Cosmetics. Budapest International Research and Critics Institute (BIRCI-Journal), 239-249.

Hierita Indah Safitri, (2016). "Perlindungan Hukum Terhadap Konsumen Atas Peredaran Kosmetik Tanpa Izin", Gloria Yuris, Vol. 4 No. 3.

Siska Diana Sari, (2018). Perlindungan Hukum Bagi Pengguna Klinik Kecantikan Estetika Berdasarkan Perspektif Hak Konstitusional Warga Negara, Jurnal Pancasila dan Kewarganegaraan, Vol.6 No 2 Oktober 2018

Rani Apriani, Candra Hayatul, and Rahmi, (2019). Tanggungjawab Pelaku Usaha Terhadap Konsumen Akibat Praktek Klinik Kecantikan Ilegal di karawang, JurnalIUS Kajian Hukum dan Keadilan, Vol. 7, No.2 Agustus 2019

Undang-Undang Dasar Tahun 1945

Undang-Undang Nomor 36 Tahun 2009 Kesehatan

Undang-Undang Nomor 29 Tahun 2004 tentang Praktik Kedokteran

Undang-Undang Nomor 8 Tahun 1999 tentang Perlindungan Konsumen

Peraturan Menteri Kesehatan Nomor 9 Tahun 2014 tentang Klinik.

Peraturan Kepala Badan Pengawas Obat dan Makanan Nomor 18 Tahun 2015 Tentang persyaratan Teknis Bahan Kosmetika

https://lampuhijau.com/berita/saat-ini-bisnis-klinik-kecantikan-sangat-prospektif-namunbanyak-tantangan-1174.php, diakses pada tanggal 17 Agustus 2019 Pukul 12.04 WIB

https://www.merdeka.com/peristiwa/fakta-mengerikan-lulusan-sma-jadi-dokter-kecantikantipu-para-wanita.html, diakses pada tanggal 6 Oktober 2019 Pukul 13.00 WIB

https://makassar.sindonews.com/read/21850/1/polda-dalami-kasus-dugaan-malpraktik-klinikkecantikan-di-makassar-1551200577, diakses pada tanggal 6 Oktober 2019 pukul 15.00 WIB.

http://www.pom.go.id/new/index.php/view/pers/316/BADAN-POM-TERUSPERANGIPEREDARAN-OBAT-ILEGAL-DI-INDONESIA.html, diakses pada tanggal 9 Oktober 2019, pukul:05:26 WIB. 